\title{
PENOLAKAN PENGURUS BESAR NAHDLATUL ULAMA (PBNU) TERHADAP KESAKSIAN HASIL RUKYAT DI BAWAH KRITERIA IMKAN AL-RUKYAH DARI TAHUN 1998 - 2017
}

\author{
Rizalluddin \\ Institut Agama Islam Cirebon \\ Email: rizalludin46@gmail.com
}

\begin{abstract}
NU is known to be consistent with rukyat as the determinant of the beginning of the Hijri month. But in practice, not all reports of rukyat testimony are accepted. There were 9 testimonies of rukyat which were considered invalid from 1998-2017, namely 1998, 2001, 2002, 2006, 2007, 2011, 2012, 2013 and 2017. As a result, the 9 testimonies were rejected by PBNU because according to contemporary reckoning at the rukyat location it had not achieve the Imkan al-rukyah criterion with minimum indicators namely crescent altitude is 2 degrees, the age at least 8 hours, or the angular distance between the moon and the Sun (elongation) is at least 3 degrees. Ibn Hajar al-Haitami's opinion which states that shahada (testimony of seeing the hilal) can be rejected if the hisāb experts agree to exclude it, and it is acceptable if the hisāb experts still dispute it as the basis for the rejection of the PBNU. The PBNU reasons for using Imkan alrukyah's criteria as the basis for rejection are; (1) to improve the quality of rukyat supported by the method of reckoning tahkiki tadkiki / ashri, NUMO (Nahdlatul Ulama Mobile Observatory), rukyat every lunar month, the number of rukyat locations is ideal; (2) Together to start the beginning of the month with the government; (3) Practices in the field; and (4) Avoiding people who act manipulatively. The writer's suggestions for the creation of rukyat consistency as a determinant of the beginning of the lunar month are; First, with NU's consistency in implementing Imkan al-rukyah in each rukyat location, $\mathrm{NU}$ can firmly reject it if there is rukyat testimony that contemporary calculations do not meet the minimum limit of Imkan alrukyah. But if at the time of the stipulation it turns out that the government through the isbat session accepts the testimony and makes the basis of rukyat as the determinant of the entry of the new month, then NU obeys the government's decision to eliminate differences; Second, when the height of the new moon in all parts of Indonesia has reached the minimum limit of Imkan al-rukyah, but in fact no one has succeeded in seeing the new moon, then NU determined the beginning of the month on the basis of istikmal, even though at that time the government through the isbat session determined based on Imkan al reckoning -rukyah. Because the government determined the entry of a new moon based solely on hisab and ignored rukyat, NU did not need to obey and follow these decrees.
\end{abstract}

Keywords: Rejection, testimony to the hilal, rukyat, PBNU 


\section{ABSTRAK}

NU yang dikenal konsisten dengan rukyat sebagai penentu awal bulan kamariah, dalam praktiknya tidak semua laporan kesaksian rukyat diterima. Ada 9 kesaksian rukyat yang dianggap tidak sah dari tahun 19982017, yaitu tahun 1998, 2001, 2002, 2006, 2007, 2011, 2012, 2013 dan 2017. Akibatnya, 9 kesaksian tersebut ditolak oleh PBNU karena menurut hisab kontemporer di lokasi rukyat belum mencapai kriteria Imkan alrukyah dengan indikator minimal tinggi hilal 2 derajat, umur bulan 8 jam, atau jarak Matahari-Bulan 3 derajat (elongasi). Pendapat Ibn Hajar alHaitami yang menyatakan bahwa syahadat (kesaksian melihat hilal) dapat ditolak jika ahli hisāb sepakat memustahilkannya, dan dapat diterima jika para ahli hisāb masih memperselisihkannya sebagai dasar pegangan penolakan PBNU. Adapun alasan PBNU menjadikan kriteria Imkan alrukyah sebagai dasar penolakan adalah; (1) untuk meningkatkan kualitas rukyat dengan didukung oleh Metode hisab tahkiki tadkiki/ashri, NUMO (Nahdlatul Ulama Mobile Observatory), rukyat setiap bulan kamariah, banyaknya lokasi rukyat ideal; (2) Bersama-sama mengawali awal bulan dengan pemerintah; (3) Praktik di lapangan; dan (4) Menghindari orangorang yang berlaku manipulatif. Adapun saran penulis demi terciptanya konsistensi rukyat sebagai penentu awal bulan kamariah adalah; Pertama, dengan konsistensi NU dalam menerapkan Imkan al-rukyah di masingmasing lokasi rukyat, secara tegas NU dapat menolak apabila terdapat kesaksian rukyat yang secara perhitungan kontemporer belum memenuhi batas minimal Imkan al-rukyah. Tetapi jika pada saat penetapan ternyata pemerintah melalui sidang isbat menerima kesaksian tersebut dan menjadikan dasar rukyat sebagai penentu masuknya bulan baru, maka NU taat terhadap keputusan pemerintah demi menghilangkan perbedaan; Kedua, pada saat ketinggian hilal di seluruh wilayah Indonesia telah mencapai batas minimal Imkan al-rukyah, namun faktanya tidak ada yang berhasil melihat hilal, maka NU menetapkan awal bulan atas dasar istikmal, walaupun pada saat itu pemerintah melalui sidang isbat menetapkan berdasarkan hisab Imkan al-rukyah. Karena pemerintah menetapkan masuknya bulan baru hanya berdasarkan hisab dan mengabaikan rukyat, NU tidak perlu taat dan ikut ketetapan tersebut.

Kata Kunci: Penolakan, Kesaksian hilal, rukyat, PBNU

\section{PENDAHULUAN}

Penolakan kesaksian rukyat (Melihat hilal (rukyatul hilal) merupakan sebuah ijtihad, adapun kebenarannya bersifat relatif. Keyakinan bahwa yang dilihatnya benar-benar hilal harus didukung pengetahuan dan pengalaman tentang pengamatan hilal. (Djamaluddin, 2005)) pertama terjadi pada tahun $1998 \mathrm{M}$. Hasil rukyatul hilal dari Jawa Timur dan Cakung ditolak karena kesaksian tersebut dianggap belum memenuhi kriteria Imkan al-rukyah dan dianggap bertentangan dengan hisab muktabar yang telah mencapai tingkat mutawatir (Hambali, 2012). Menteri Agama dan NU sama-sama menetapkan 1 Syawal $1418 \mathrm{H}$ jatuh pada Jum'at Kliwon, 30 Januari 1998 M, atas dasar istikmal. Walaupun NU yang dikenal konsisten dengan rukyat sebagai penentu awal bulan kamariah, 
dalam praktiknya tidak semua laporan kesaksian rukyat diterima oleh PBNU, di mana PBNU sebagai pemegang wewenang ikbar/inforomasi (LF PBNU, 2006). Sedangkan dalam pelaksanaannya didelegasikan kepada Lembaga Falakiyah Pengurus Besar Nahdlatuh Ulama ( LF PBNU, 2006) yang bertugas mengelola masalah rukyat, hisab dan pengembangan ilmu falak (AD ART PBNU, 2015).

Penolakan kesaksian rukyat kembali terjadi pada tahun 2006 mengawali 1 Syawal $1427 \mathrm{H}$. Dalam almanak PBNU 2006 yang diterbitkan oleh LFNU telah menginformasikan tentang data hisab menjelang Idul Fitri $1427 \mathrm{H}$, data hisab menyatakan, bahwa pada tanggal 29 malam 30 Ramadan $1427 \mathrm{H}$ bertepatan dengan tanggal 22 Oktober 2006 ketika Matahari terbenam, tinggi hilal $0^{\circ} 54$ ', ini artinya belum memenuhi kriteria Imkan al-rukyah dan kemungkinan melihat hilal sangat sulit sehingga kebenaran hasil rukyat di Gebang Bangkalan Madura diragukan. Penolakan PBNU terhadap kesaksian rukyat ini menimbulkan permasalahan intern di tubuh NU, yaitu PBNU mengikbarkan 1 Syawal $1427 \mathrm{H}$ jatuh pada hari Selasa, 24 Oktober 2006 atas dasar istikmal dan menolak kesaksian rukyat di Bangkalan, sedangkan PWNU Jawa Timur mengikbarkan 1 Syawal 1427 $\mathrm{H}$ jatuh pada hari Senin, 23 Oktober 2006 atas dasar rukyatul hilal ( LF PBNU, 2006).

Kasus hampir serupa terjadi pada tahun 2011, tepatnya dalam mengawali 1 Syawal $1432 \mathrm{H}$. Lokasi rukyat di pantai Kartini melaporkan berhasil melihat hilal dan disampaikan ke PBNU. Tetapi data hisab menyatakan, bahwa ketinggian hilal masih di bawah kriteria Imkan alrukyah sehingga kesaksian rukyat tersebut ditolak. Namun, kali ini PWNU Jawa Timur tidak mengikbarkan tetapi menunggu PBNU melakukan sidang isbat dengan pemerintah dan hasilnya PBNU mengikbarkan bahwa 1 Syawal 1432 H jatuh pada hari Rabu, 31 Agustus 2011 (Hambali, 2017).

Penolakan kesaksian rukyat kembali terjadi pada tahun 2017, tepatnya dalam mengawali 1 Muharram $1439 \mathrm{H}$ berdasarkan hasil laporan rukyatul hilal dari berbagai daerah yang diselenggarakan pada Rabu 20 September 2017 terdapat 1 pos (lokasi rukyat) dengan 2 saksi perukyat yang menyatakan berhasil melihat hilal. Lokasi rukyat tersebut adalah Gedung ponpes Baitul Hikmah kelurahan krampyangan kota Pasuruan, melaporkan bahwa hilal dapat dilihat oleh Ust. Sofiyul Muhibbin Sidogiri dengan menggunakan teleskop Ioptron IEQ 30 Pro dan Ust. H. Inwanudin Gresik dengan kasat mata. Tetapi PBNU justru menolak kesaksian tersebut dan melakukan istikmal ( LF PBNU, 2006), sehingga terjadi perbedaan awal bulan Muharram $1439 \mathrm{H}$, dimana pemerintah dan ormas lain sepakat jatuh pada hari Kamis, 21 September 2017 sedangkan NU melalui LFNU mengikbarkan jatuh pada hari Jum'at, 22 September 2017.

Penolakan hasil rukyat 1 Muharram $1439 \mathrm{H}$ ini sempat menjadi viral. Padahal jika dilihat dari ritual ibadah pada bulan tersebut tidaklah sebesar bulan Ramadan, Syawal dan Zulhijah. Tetapi penolakan ini menjadi perbincangan anggota masyarakat NU khususnya dan para pemerhati ilmu falak pada umumnya. Alasannya, pertama, pemerintah melalui Tim Hisab Rukyat (THR) beserta organisasi masyarakat lain seperti Muhammadiyah, Persis sepakat bahwa 1 Muharram 1439 H jatuh pada Kamis, 21 September 
2017 karena menurut data perhitungan menyatakan di bagian Barat Indonesia telah memenuhi kriteria Imkan al-rukyah (Ikhbar PBNU, 2017). Kedua, orang yang berhasil melihat hilal adalah orang yang selama ini kesaksiannya selalu diterima oleh PBNU dan dijadikan penentu atas dasar rukyat sebagai masuknya bulan baru, kredibilitasnya berdasarkan pengalaman rukyat tidak diragukan, tetapi karena di lokasi rukyat tersebut posisi hilal belum mencapai kriteria Imkan al-rukyah maka PBNU menolak kesaksian tersebut dan melakukan istikmal.

Berangkat dari penjelasan di atas, perlu kiranya untuk dikaji terkait lebih dalam mengenai Alasan PBNU menjadikan kriteria Imkan al-rukyah sebagai dasar penolakan kesaksian rukyat.

\section{METODE PENELITIAN}

Penelitian ini merupakan jenis penelitian kualitatif dengan kajian penelitian kepustakaan/literatur. Sumber data yang digunakan adalah buku "Pedoman Rukyat dan Hisab Nahdhatul Ulama" dan "Laporan Lajnah Falakiyah kepada PBNU tentangPenyelenggaraan Rukyat untuk Idul Fitri $1427 H^{\prime \prime}$ sebagai sumber data primer serta buku-buku yang membahas persoalan penentuan awal bulan kamariah sebagai sumber data sekunder. Metode pengumpulan data dilakukan dengan cara dokumentasi dan wawancara (interview). Semua data dianalisis dengan metode deskriptifanalitis dan pendekatan historis yang terfokus pada penolakan PBNU terhadap kesaksian di bawah Imkan al-rukyah.

\section{PEMBAHASAN}

A. Metode Penentuan Awal Bulan Kamariah Nahdlatul Ulama

Pada dasarnya NU berpegang pada putusan Muktamar NU ke-27 tahun 1405 H/Tahun 1984 di Situbondo dan Munas Alim Ulama Nahdlatul Ulama di Cilacap tahun 1409 H/1987 M bahwa penentuan awal bulan kamariah, khususnya bulan Ramadan, Syawal, dan Zulhijah wajib didasarkan atas Rukyatul Hilal bil Fi'li atau Istikmal. Sedangkan kedudukan hisab hanyalah sebagai pembantu dalam melakukan rukyat (LF PBNU, 2006). Rukyatul hilal inilah yang menjadi asas pokok yaitu asas ta'abbudi (تعبدي) atau asas kepatuhan, yakni patuh memberlakukan seluruh nash yang ada dalam AlQur'an dan As-Sunnah, untuk kesempurnaannya, NU menggunakan asas ta'aqquli (تعقلي) atau asas penalaran yakni menggunakan ilmu hisab/astronomi sebagai instrumen dan pemandu rukyat, bukan untuk menggantikan rukyat (Masroeri, 2011).

Dijelaskan dalam Musyawarah Nasional Alim Ulama Nahdlatul Ulama yang berlangsung pada tanggal 13-16 Rabiul Awwal 1404/ 18-21 Desember 1983 M di Sukorejo, Situbondo Jawa Timur bahwa:

Penetapan Pemerintah tentang awal Ramadan dan awal Syawal dengan menggunakan dasar hisab, tidak wajib diikuti. Sebab menurut Jumhur Salaf bahwa tsubut awal Ramadan dan awal Syawal itu hanya birru'yah au itmamil adadi tsalatsina yauman." (Muktamar NU,1985)

Selanjutnya, keputusan tersebut dikukuhkan dalam Munas Alim Ulama di Cilacap 1987 dan rapat kerja Lajnah Falakiyah NU di Pelabuhan Ratu 1992: 
1. Bahwa dasar ru'yah al-hilal atau istikmal dalam penetapan awal Ramadan, Idul Fitri, dan Idul Adha adalah adalah dasar yang diamalkan oleh Rasul dan Khulafaur Rasyidin dan dipegangi oleh seluruh ulama mazahib al-arba'ah. Sedang dasar hisāb falak untuk penetapan tiga hal ini ialah dasar yang tidak pernah diamalkan oleh Rasulullah dan Khulafaur Rasyidin serta diperselisihkan keabsahannya di kalangan para ulama.

2. Bahwa isbat 'am (penetapan secara umum) oleh Qadli atau penguasa mengenai awal Ramadan, Idul Fitri, dan Idul Adha atas dasar hisāb tanpa dihasilkan rukyat al-hilāl atau istikmāl adalah tidak dibenarkan oleh mazhab empat (Hanafi, Maliki, Syafi'i, dan Hambali).

3. Bahwa Nahdlatul Ulama adalah jam'iyah yang berhaluan Aswaja (AD pasal 4), yaitu jam'iyah yang menjunjung tinggi dan mengikuti agama Rasulullah dan tuntunan sahabat serta ijtihad para ulama mazhab empat.

4. Bahwa Munas Alim Ulama NU tanggal 13-16 Rabiul awal 1404 H/18 21 Desember 1983 di Situbondo telah mengambil keputusan mengenai penetapan awal Ramadan dan Idul Fitri yang intinya bahwa NU menggunakan dasar rukyat al-hilāl atau istikmāl. Keputusan ini telah dikukuhkan oleh Muktamar NU ke-27 th. 1405 H/1984 M.

5. Dan untuk keseragaman di kalangan warga NU dalam melaksanakan keputusan yang dimaksud dalam hal penetapan mengenai Idul Adha, maka Munas Alim Ulama yang berlangsung tanggal 23-24 Rabiul awal 1408 H/15-16 November 1987 di Pondok Pesantren Ihya Ulumuddin Kesugihan, Cilacap, Jawa Tengah, telah mengambil keputusan sebagai berikut :

a. Menegaskan bahwa penetapan awal Ramadan, Idul Fitri, dan Idul Adha oleh Qadli atau penguasa yang diberlakukan kepada masyarakat setempat (isbat al-'ām) dapat dibenarkan jika berdasarkan rukyat al-hilāl atau istikmāl.

b. NU telah lama mengikuti pendapat ulama yang tidak membedakan matla' dalam penetapan awal Ramadan, Idul Fitri, dan Idul Adha, yakni rukyat al-hilāl di salah satu tempat di Indonesia yang diterima oleh pemerintah sebagai dasar penetapan awal Ramadan, Idul Fitri, dan Idul Adha berlaku di seluruh wilayah Indonesia walaupun berbeda matla'nya.

c. Melakukan rukyat al-hilāl untuk penetapan awal Ramadan, Idul Fitri, dan Idul Adha adalah fardu kifayah menurut mazahib alarba'ah kecuali mazhab Hambali yang berpendapat bahwa hukumnya sunnah. Pelaksanaan rukyat al-hilāl yang diusahakan pemerintah/Depag adalah sudah cukup sebagai pelaksanaan fardlu kifayah tersebut bagi seluruh umat Islam Indonesia. 
d. Lajnah Falakiyah PBNU perlu melakukan upaya bagi terlaksananya prinsip rukyat al-hilāl atau istikmāl antara lain dengan cara :

i. Membuat kepastian awal Syakban dengan rukyat al-hilāl atau istikmāl untuk keperluan awal Ramadan.

ii. Melakukan rukyat al-hilāl pada malam 30 Syawal dan 30 Zulhijah selanjutnya menanyakan hasil rukyat al-hilāl tanggal 1 Zulhijah kepada pemerintah. Hal ini dilakukan sebab sering kali pemerintah tidak mengeluarkan pengumuman penetapan tanggal 1 Zulhijah secara rinci, kemudian hasilnya diumumkan kepada wilayah dan cabang NU di seluruh Indonesia untuk keperluan Idul Adha segera .

e. Untuk keperluan memulai puasa Ramadan, melaksanakan Idul Fitri dan menyelenggarakan Idul Adha, maka kepada warga NU terutama anggota pimpinan dari tingkat pusat sampai dengan tingkat ranting diinstruksikan agar menyimak pengumuman dan penetapan pemerintah/Depag melalui RRI dan TVRI mengenai tiga hal. Jika pengumuman dan penetapannya berdasarkan rukyat al-hilāl atau istikmāl, maka warga NU wajib mengikuti dan menaatinya, tetapi jika pengumuman dan penetapannya hanya semata-mata berdasarkan hisāb, maka warga NU tidak wajib mengikuti dan menaatinya, selanjutnya menyuruh puasa Ramadan, melaksanakan Idul Fitri, dan menjalankan Idul Adha pada hari berikutnya (Izzuddin, 2007).

B. Penolakan-penolakan Pengurus Besar Nahdlatul Ulama (PBNU) Terhadap Kesaksian Hasil Rukyat di bawah Imkan al-rukyah dari Tahun 1998-2017

Penolakan Nahdlatul Ulama terhadap kesaksian rukyat di bawah Imkan al-rukyah dari tahun 1998-2017 terjadi sebanyak 9 (sembilan) kali, yaitu tahun 1998, 2001, 2002, 2006, 2007, 2011, 2012, 2013 dan 2017. Kesaksian rukyat tersebut dilaporkan dari 6 lokasi rukyat, yaitu Pantai Prapat Tunggal Bawean Jawa Timur (550'56,52” LS 112³9'45,01 BT), Cakung Jakarta Timur (6'9'35,22” LS 106'55'52,18 BT), Pantai Serang Panggung Rejo Blitar (8¹9'53,66” LS 112'13'22,58 BT), Gebang Bangkalan Madura (6॰59'20,7” LS 112॰47'22,7 BT), Pantai Kartini Jepara (6॰35'20,76” LS 110॰38'41,80 BT) dan Pasuruan Jawa Timur (7॰39'39,68” LS 11254'48, 17 BT). Dari 6 lokasi tersebut, Cakung Jakarta Timur sebanyak 7 kali menyampaikan bahwa hilal dapat dilihat, yaitu pada tahun 1998, 2002, 2006, 2007, 2011, 2012, dan 2013 sedangkan sisa lokasi rukyat lainnya hanya sekali melaporkan hilal dapat terlihat.

Tabel 1

Penolakan Kesaksisan Rukyat 


\begin{tabular}{|c|c|c|c|c|c|}
\hline & & \multicolumn{2}{|c|}{ dalam } & \multirow[b]{2}{*}{ Pemerintah } & \multirow[b]{2}{*}{ PBNU } \\
\hline & & $\begin{array}{c}\text { Sidang } \\
\text { Isbat }\end{array}$ & PBNU & & \\
\hline 1 & 1998 & $\checkmark$ & - & Istikmal & Istikmal \\
\hline 2 & 2001 & - & $\checkmark$ & $\begin{array}{l}\text { Tidak } \\
\text { Istikmal }\end{array}$ & Istikmal \\
\hline 3 & 2002 & - & $\checkmark$ & $\begin{array}{l}\text { Tidak } \\
\text { Istikmal }\end{array}$ & $\begin{array}{l}\text { Tidak } \\
\text { Istikmal }\end{array}$ \\
\hline 4 & 2006 & $\checkmark$ & - & Istikmal & Istikmal \\
\hline 5 & 2007 & $\checkmark$ & - & Istikmal & Istikmal \\
\hline 6 & 2011 & $\checkmark$ & - & Istikmal & Istikmal \\
\hline 7 & 2012 & $\checkmark$ & - & Istikmal & Istikmal \\
\hline 8 & 2013 & $\checkmark$ & - & Istikmal & Istikmal \\
\hline 9 & 2017 & - & $\checkmark$ & $\begin{array}{l}\text { Tidak } \\
\text { Istikmal }\end{array}$ & Istikmal \\
\hline
\end{tabular}

Sementara menurut perhitungan kontemporer di masing-masing lokasi rukyat adalah sebagai berikut. Pada tahun $1998 \mathrm{M}$ dalam mengawali Syawal $1418 \mathrm{H}$, menurut hisab, data hilal di lokasi rukyat Cakung Jakarta Timur adalah ketinggian hilal dari horizon $0^{\circ} 20^{\prime} 3,8$ ", umur Bulan $5 \mathrm{j} 13^{\mathrm{m}}$ 48 dan elongasi 30 52' 48,6”. Sedangkan di lokasi rukyat Pantai Prapat Tunggal Bawean Jawa Timur ketinggian hilal 0o 9' 31", umur Bulan 4j 51 m $36^{d}$ dan elongasi $3^{\circ} 44^{\prime} 28^{\prime}$. Kemudian, pada tahun 2001, tepatnya dalam menetapkan 1 Zulhijah $1421 \mathrm{H}$, ketinggian hilal 1'36'30,4”, umur Bulan 2j $31^{\mathrm{m}} 48^{\mathrm{d}}$ dan elongasi $4^{\circ} 1^{\prime}$ ' 0,6" di lokasi rukyat Pantai Serang Panggung Rejo Blitar. Dan satu tahun kemudian, yaitu 1 Zulhijah $1422 \mathrm{H}$ di lokasi rukyat Cakung Jakarta Timur, data hilal menunjukan ketinggian hilal $1^{\circ} 53^{\prime}$ 25,5”, umur bulan 3j 32m 24d dan elongasi 4o $39^{\prime} 15,4^{\prime \prime}$

Selanjutnya, pada penolakan ketiga tahun 2006 dalam mengawali Syawal $1427 \mathrm{H}$, data hisab menunjukan bahwa ketinggian hilal 0¹6' 19,2", umur Bulan 5j 6m 36' dan elongasi 3051' 6" di lokasi Gebang Bangkalan Madura dan di Cakung ketinggian hilal 0¹9' 57", umur Bulan 5j 28m 48d dan elongasi 3०57' 57,8”. Satu tahun kemudian, yaitu tahun 2007 di lokasi Cakung Jakarta Timur melaporkan bahwa hilal dapat dilihat, dimana menurut data hisab di lokasi tersebut tinggi hilal $0^{\circ} 8^{\prime} 14,1^{\prime \prime}$, umur Bulan $5^{j}$



Pada tahun 2011 dalam mengawali bulan Syawal $1432 \mathrm{H}$, data hisab menunjukan bahwa di lokasi Pantai Kartini Jepara ketinggian hilal 1'20' 14,5", umur Bulan $7^{\mathrm{j}} 31^{\mathrm{m}} 4^{\mathrm{d}}$ dan elongasi mencapai 6०34' 30,8". Sedangkan di lokasi Cakung Jakarta Timur ketinggian hilal 1'23'25,8”, umur Bulan $7^{\mathrm{j}} 46^{\mathrm{m}} 12^{\mathrm{d}}$ dan elongasi mencapai 6040' 14,9”. Satu tahun kemudian, yaitu tahun 2012 di lokasi Cakung Jakarta Timur sendirian bersaksi bahwa hilal dapat dilihat, sementara data hisab menunjukan ketinggian hilal 1'22' 29,8”, umur Bulan 6j 25m 48d dan elongasi 517' 16,7”. Di tahun berikutnya, dalam rukyat 29 Syakban 1434 H / 2013 M, kembali Cakung Jakarta Timur sendirian bersaksi bahwa hilal dapat dilihat, sementara data hisab menunjukan ketinggian hilal 0¹9' 47,6”, umur Bulan $3^{\mathrm{j}} 33^{\mathrm{m}} 36^{\mathrm{d}}$ dan elongasi $4047^{\prime}$ ' 15, $1^{\prime \prime}$. 
Dalam menetapkan 1 Muharram 1439 H / 2017 M, NU kembali menolak kesaksian rukyat. Laporan disampaikan dari lokasi rukyat Gedung ponpes Baitul Hikmah kelurahan krampyangan kota Pasuruan. Data hisab tanggal 29 Zulhijah menunjukan ketinggian hilal di lokasi tersebut adalah

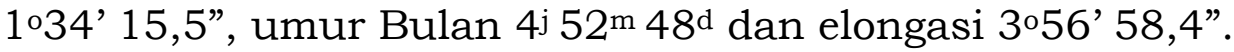

Tabel 2

Data Hilal di Lokasi Rukyat yang Ditolak

\begin{tabular}{|c|c|c|c|c|c|}
\hline No. & $\begin{array}{l}\text { Lokasi } \\
\text { Rukyat }\end{array}$ & Tahun & $\begin{array}{l}\text { Tinggi } \\
\text { Hilal }\end{array}$ & $\begin{array}{l}\text { Umur } \\
\text { Bulan }\end{array}$ & Elongasi \\
\hline 1. & Cakung & 1998 & \begin{tabular}{ll|}
$0^{\circ}$ & $20^{\prime}$ \\
$3,8^{\prime \prime}$ & \\
\end{tabular} & $\begin{array}{ll}5^{j} & 13^{m} \\
48^{d} & \\
\end{array}$ & $\begin{array}{l}3^{\circ} 52^{\prime} \\
8,6^{\prime \prime}\end{array}$ \\
\hline 2 . & Bawean & 1998 & 0० 9' 31 " & $\begin{array}{ll}4 j & 51^{\mathrm{m}} \\
36^{\mathrm{d}} & \end{array}$ & $\begin{array}{l}3^{\circ}, 44^{\prime} \\
28^{\prime \prime}\end{array}$ \\
\hline 3. & $\begin{array}{l}\text { Pantai } \\
\text { Serang } \\
\text { Blitar }\end{array}$ & 2001 & $\begin{array}{l}1^{\circ}{ }^{3} 36^{\prime} \\
30,4^{\prime \prime}\end{array}$ & $\begin{array}{l}2^{\mathrm{j}} \quad 31^{\mathrm{m}} \\
48^{\mathrm{d}}\end{array}$ & $\begin{array}{ll}40 & 10 \\
0,6 ” & \end{array}$ \\
\hline 4. & Cakung & 2002 & $\begin{array}{l}1^{\circ}{ }^{\circ} 53^{\prime} \\
25,5^{\prime \prime}\end{array}$ & $\begin{array}{ll}3 \mathrm{j} & 32^{\mathrm{m}} \\
24{ }^{\mathrm{d}} & \\
\end{array}$ & 4०39'5,4" \\
\hline 5. & $\begin{array}{l}\text { Gebang } \\
\text { Bangkalan }\end{array}$ & 2006 & $\begin{array}{l}0^{\circ} 16^{\prime} \\
19,2 "\end{array}$ & $5^{\mathrm{j}} 6^{\mathrm{m}} 36^{\mathrm{d}}$ & 3०51' 6" \\
\hline 6. & Cakung & 2006 & $\begin{array}{l}0^{\circ} 19^{\prime} \\
57^{\prime \prime}\end{array}$ & $\begin{array}{ll}5^{j} & 28^{m} \\
48^{d} & \end{array}$ & $\begin{array}{l}3^{\circ} 57^{\prime} \\
7,8^{\prime \prime}\end{array}$ \\
\hline 7. & Cakung & 2007 & $\begin{array}{l}0 \circ 8^{\prime} \\
14,1 "\end{array}$ & $\begin{array}{ll}5 j & 42^{\mathrm{m}} \\
36^{\mathrm{d}} & \\
\end{array}$ & $\begin{array}{l}4^{\circ} 24^{\prime} \\
5,4^{\prime \prime}\end{array}$ \\
\hline 8. & $\begin{array}{l}\text { Pantai } \\
\text { Kartini }\end{array}$ & 2011 & $\begin{array}{l}10^{\circ} 20^{\prime} \\
14,5^{\prime \prime}\end{array}$ & $\begin{array}{ll}7 \mathrm{j} & 31^{\mathrm{m}} \\
48^{\mathrm{d}} & \end{array}$ & $\begin{array}{l}6^{\circ} 34^{\prime} \\
0,8^{\prime \prime}\end{array}$ \\
\hline 9. & Cakung & 2011 & $\begin{array}{l}10^{\circ} 23^{\prime} \\
25,8^{\prime \prime}\end{array}$ & $\begin{array}{ll}7 \mathrm{j} & 46^{\mathrm{m}} \\
12^{\mathrm{d}} & \\
\end{array}$ & $\begin{array}{l}6040^{\prime} \\
4,9 ”\end{array}$ \\
\hline 10. & Cakung & 2012 & $\begin{array}{l}1^{\circ} 22^{\prime} \\
29,8^{\prime \prime}\end{array}$ & $\begin{array}{ll}6 j & 25^{m} \\
48^{d} & \end{array}$ & $\begin{array}{l}5^{\circ} 17^{\prime} \\
6,7^{\prime \prime}\end{array}$ \\
\hline 11. & Cakung & 2013 & $\begin{array}{l}019 ' \\
47,6 "\end{array}$ & $\begin{array}{ll}3 \mathrm{j} & 33^{\mathrm{m}} \\
36^{\mathrm{d}} & \\
\end{array}$ & $\begin{array}{l}4 \circ 47^{\prime} \\
5,1^{\prime \prime}\end{array}$ \\
\hline 12. & Pasuruan & 2017 & $\begin{array}{l}\text { 1०34' } \\
15,5^{\prime \prime}\end{array}$ & $\begin{array}{ll}4 j & 52^{m} \\
48^{d} & \\
\end{array}$ & $\begin{array}{l}3^{\circ} 56^{\prime} \\
8,4^{\prime \prime}\end{array}$ \\
\hline
\end{tabular}

Dari data di atas, dapat dipahami bahwa memang betul data hilal pada saat pelaksanaan rukyat belum mencapai kriteria Imkan al-rukyah, sehingga kesaksian pada saat itu ditolak dan dianggap sebagai rukyat yang bermasalah. Namun, jika diperhatikan lebih seksama, ternyata elongasi Bulan dari 9 kasus penolakan sudah melewati batas minimal Imkan alrukyah yang hanya $3^{\circ}$, semua tempat rukyat menunjukan data elongasi di atas $3^{\circ}$ bahkan ada yang mencapai 2 kali lipat batas minimal Imkan alrukyah, yaitu $6^{\circ}$.

C. Alasan Imkan al-rukyah Dijadikan Dasar Penolakan Kesaksian Rukyat Perspektif NU, dasar rukyat al-hilāl ini menjadi asas pokok bagi penetapan awal bulan Ramadan, Syawal, dan Zulhijah, yaitu asas ta'abbudī 
atau asas kepatuhan, yakni patuh memberlakukan seluruh nas yang terdapat dalam al-Quran dan as-Sunnah tentang rukyat al-hilāl. Adapun untuk kesempurnaannya, NU menerapkan asas ta'aqquli atau asas penalaran, yakni menggunakan ilmu hisāb atau astronomi dengan pendekatan imkān ar-rukyat (yang tertuang dalam bentuk Almanak) sebagai instrumen dan pemandu rukyat, dan bukan sebagai pengganti rukyat (Masroeri, 2011).

NU mulai memfungsikan hisab sebagai pengontrol keabsahan rukyat (Nawawi, 2004 ). Ketetapan NU menjadikan hisāb sebagai pengontrol ini menjadi pedoman untuk memilah hasil rukyat al-hilāl yang sah dan yang tidak sah. Secara syar'̄̄ sikap NU ini didasarkan pada pendapat Ibn Hajar al-Haitami yang menyatakan bahwa syahadat (kesaksian melihat hilal) dapat ditolak jika ahli hisāb sepakat memustahilkannya, dan dapat diterima jika para ahli hisāb masih memperselisihkannya (al-Haitami, 1983), sehingga tidak semua laporan kesaksian rukyat diterima oleh NU. NU menolak keabsahan hasil rukyat bila menurut hisab Bulan masih belum melahirkan hilal (Nawawi, 2004).

Pendapat Ibn Hajar al-Haitami ini adalah jalan tengah yang ditawarkan ketika hasil rukyat berbeda dengan hasil hisab (Nawawi, 2004). Apabila terjadi rukyat tersebut bertentagan denga hisab qath'i maka rukyat tersebut harus ditolak/tidak diterima, sebab rukyat itu berdasarkan hissi (pandangan mata), sedangkan hissi statusnya dhanni. Yang dimaksud dengan hisab qath'i ialah apabila tercapai kesepakatan diantara ahli hisab berdasarkan kaidah-kaidah hisab mereka bahwa keadaan hilal mustahil dapat dirukyat pada tempat tersebut. Sebaliknya, apabila ahli hisab berselisih maka rukyat dimenangkan. Sebab di sini berarti terjadi perlawanan antara dua dhan (rukyat) dan satu dhan (hisab). Maka yang dimenangkan tentu yang memiliki dua dhan (rukyat). Dengan adanya pertentangan dikalangan ahli hisab berarti ada dua dhan dalam rukyat, yaitu satu dhan dari pihak yang menyatakan rukyat dan satu dhan lagi dari pihak ahli hisab yang menyatakan tidak mustahil rukyat (Hosen, 2004).

Hisab pengontrol yang dipegangi oleh NU sekarang ini adalah kriteria Imkan al-rukyah. Kriteria Imkan al-rukyah yang dipakai oleh NU adalah kriteria Cisarua 1998 dan 2011. Pada tanggal 24-26 Maret 1998 di- hotel USSU Cisarua, rapat anggota Badan Hisab Rukyah (BHR) telah menyepakati kriteria Imka>n al-rukyah sebagai berikut: (1) Tinggi hilal mar'i di lokasi perukyah minimal $2^{\circ}$ dihitung menggunakan hisab hakiki bit tahqiq/kontemporer, (2) Umur Bulan minimal 8 jam, dan (3) Beda Azimut minimal $3^{\circ}$. Kriteria tersebut diperbarui pada tahun 2011, yakni pada tanggal 19-21 September 2011 di hotel USSU Cisarua, rapat anggota Badan Hisab Rukyah (BHR) telah menyepakati kriteria imkan arrukyat sebagai berikut: (1) Tinggi hilal mar'i di lokasi perukyah minimal $2^{\circ}$ dihitung menggunakan hisab hakiki bit tahqiq/kontemporer, (2) Umur Bulan minimal 8 jam atau elongasi minimal $3^{\circ}$ (Amri,2011).

Adapun alasan NU memilih kriteria Imkan al-rukyah sebagai hisab pengontrol dan menjadikan dasar penolakan kesaksian rukyat adalah sebagai berikut:

1. Meningkatkan Kualitas Rukyat. 
Rukyat yang berkualitas adalah rukyat yang secara astronomis dapat dibenarkan dan dipertanggungjawabkan (rukyat yang mu'tabar (Jayusman, 2011)). Adanya laporan bahwa hilal berhasil dilihat dalam mengawali Syawal tahun $1412 \mathrm{H}(1992 \mathrm{M}), 1413 \mathrm{H}$ (1993 M) dan 1414 H (1994 M) yang kemudian oleh NU dijadikan dasar penentuan awal bulan kamariah dan menyebabkan perbedaaan antara NU dan pemerintah, secara astronomis rukyat tersebut tidak dapat dibenarkan dan dipertanggungjawabkan. Secara astronomis, sangatlah tidak mungkin hilal dapat terlihat pada saat Matahari terbenam, hilal sudah di bawah ufuk, bahkan sebelum Matahari terbenam, hilal sudah lebih dahulu terbenam.

NU yang pada saat itu masih berpegang teguh pada dasar rukyat murni mulai dipertanyakan validitas hasil rukyat-nya. Maka kemudian, langkah yang ditempuh oleh NU dalam mewujudkan rukyat yang berkualitas adalah mengadopsi kriteria Imkan alrukyah. Dengan kriteria ini, rukyat dapat dipertanggungjawabkan secara astronomis, digunakan untuk memilah hasil rukyat al-hiläl yang sah dan yang tidak sah. Ada beberapa hal yang mendukung NU dalam mewujudkan rukyat yang berkualitas, diantaranya:

a. Metode Hisab Tahkiki Tadkiki/Ashri

Perbedaan yang terjadi antara NU dan Pemerintah pada tahun 1992,1993 dan 1994 disinyalir karena hisab yang digunakan adalah taqribi, tingkat akurasinya rendah dan belum menggunakan koreksi-koreksi, sehingga data hisab yang disajikan menyatakan bahwa hilal sudah berada di atas ufuk dengan ketinggian yang cukup tinggi, maka terdapat laporan rukyat dari Jawa Timur dan Cakung yang kemudian dijadikan dasar atas masuknya bulan Syawal, padahal menurut data hisab kontemporer atau hisab hakiki yang memiliki tingkat akurasi tinggi, sudah menggunakan koreksikoreksi justru posisi hilal masih di bawah ufuk. Tidak heran pada saat itu ritual rukyat NU menjadi bahan cibiran dan cemoohan.

Berangkat dari pengalaman tersebut, akhirnya NU berusaha meningkatkan kualitas rukyat. Salah satu caranya adalah dengan meninggalkan metode hisab taqribi secara keseluruhan dan beralih menggunakan metode hisab tahkiki tadkiki/ashri atau kontemporer. Sebagaimana telah dijelaskan dimuka, bahwa dalam menentukan awal bulan kamariah, NU melalui 4 (empat) tahap, dimana tahap pertamanya adalah hisab. Menurut NU, hisab dapat dijadikan sebagai pendukung dalam menentukan awal bulan kamariah, tidak sebagai penentu karena hisab sifatnya prediktif.

b. NUMO

Dalam rangka meningkatkan kualitas dan kemampuan rukyat dijajaran perukyat Nahdiyyin, Lembaga Falakiyah 
Nahdlatul Ulama membuat sebuah sarana rukyat modern yang disebut NUMO, singkatan dari Nahdlatul Ulama Mobile Observatory ataupun Nusantara Mobile Observatory. NUMO merupakan generasi kedua setelah Indonesia Mobile Observatory (IMO) yang diprakarsai oleh seorang pegiat astronomi, Hendro Setyanto, M.si. yang juga anggota Penelitian dan Pengembangan LFNU (Mushlih, 2018).

Dalam konteks program, NUMO akan menjadi program unggulan dari Lembaga Falakiyah Nahdlatul Ulama khususunya berkaitan dengan program pengembangan ilmu pengetahuan khususnya Ilmu Falak serta pelayanan masyarakat. Urgensi kehadiran NUMO menjadi penting ketika dihadapkan pada persoalan minimnya sebagian masyarakat yang "melek" IT dan pengayaan teori yang kadang tidak berbanding lurus dengan praktik.

Dalam melaksanakan programnya, NUMO akan menjelajah dalam bentuk mobil yang dilengkapi dengan berbagai perangkat IT khususnya tentang dunia astronomi. NUMO merupakan wahana bergerak yang dirancang untuk melakukan penelitian, pendidikan dan sosialisasi ilmu falak (Rukyat dan Hisab) secara bersamaan. Untuk melaksanakan fungsinya, NUMO dilengkapi dengan perangkat penelitian astronomi dan sosialisasi sebagai berikut (Masroeri, 2018):

1) Teleskop APO yang dengan spesifikasi diameter $<100$ $\mathrm{mm}$ dan panjang fokus $<500 \mathrm{~mm}$ merupakan teleskop yang optimal untuk keperluan rukyat sekaligus menikmati keindahan benda-benda langit, seperti permukaan Bulan, Matahari, gugus bintang, serta planet. Teleskop tersebut dipasang pada sebuah dudukan teleskop yang disebut Mount.

2) Goto Mount merupakan dudukan teleskop yang dilengkapi dengan kemampuan pointing dan tracking benda-benda langit secara otomatis. Pointing merupakan kemampuan mount untuk menggerakan teleskop ke arah benda langit sedangkan tracking, merupakan kemampuan mount untuk mengikuti gerak benda langit.

3) Komputer kontrol yang terhubung dengan mount memungkinkan perukyat mengontrol pergerakan teleskop secara remote. Di samping itu komputer kontrol dapat digunakan untuk mengolah citra yang diperoleh dari detektor yang dipasang pada teleskop.

4) TV 32 inch digunakan sebagai monitor komputer sehingga aktivitas untuk mengontrol gerak teleskop dan menampilkan objek yang dibidik oleh teleskop dapat dilihat bersama-sama. Hal ini merupakan salah satu 
bentuk proses pembelajaran terhadap publik yang sangat efisien.

5) Detektor merupakan sarana untuk mengumpulkan informasi dalam bentuk citra. Detektor yang digunakan berupa kamera digital dan video CCD.

6) Teleskop manual dimaksudkan untuk keperluan pembelajaran publik dan sosialisasi akan hakikat ilmu falak. Diharapkan masyarakat dapat mengetahui dengan baik permasalahan-permasalahan yang terkait dengan ilmu falak.

7) Theodolite digunakan untuk keperluan pengukuran arah kiblat dan juga rukyatul hilal.

8) Navigator GPS yang merupakan perangkat digital yang dimaksudkan untuk menunjukan posisi (lintang-bujur). Informasi posisi yang akurat merupakan salah satu point penting yang menunjang kesuksesan pengamatan secara digital. Disamping itu, sebagai sebuah Navigator perangkat tersebut dapat menuntun arah perjalanan NUMO menuju lokasi yang diharapkan dengan tepat.

c. Rukyat Setiap Bulan Kamariah

NU menetapkan bahwa penentuan awal bulan kamariah selain Ramadan dan Syawal adalah tetap berdasarkan rukyat berdasarkan metode mengqiyaskan hukum bulan lain pada hadis nabi tentang rukyat dan adat kebiasaan masyarakat arab (Direktorat Jendral Bimbingan Masyarakat Islam Kementrian Agama RI, 2010). Dengan adanya almanak NU yang merupakan hasil dari hisab jama'i atau hisab penyerasian dari berbagai hisab kontemporer dapat membantu LF PBNU untuk memberikan intruksi kapan dilaksanakannya rukyat, selain masing-masing lokasi rukyat juga sudah pasti melakukan perhitungan sendiri sebelum rukyat dilaksanakan.

Ada intruksi ataupun tidak ada dari LF PBNU, warga Nahdlatul Ulama yang bertugas di lokasi-lokasi rukyat setiap tanggal 29 bulan kamariah pasti melaksanakan rukyat, bagaimanapun keadaaan hilalnya baik sudah di atas ufuk maupun di bawah ufuk (Masroeri, 2018). Apabila ketika itu hilal dapat teramati, maka pada malam itu dimulai tanggal 1 bagi bulan baru atas dasar rukyatulhilal. Namun apabila tidak berhasil melihat hilal, maka malam itu adalah tanggal 30 dari bulan yang sedang berjalan dan kemudian malam berikutnya dimulai tanggal 1 bagi bulan baru atas dasar istikmal (menggenapkan 30 hari bagi bulan sebelumnya) (Junaidi, 2010). Ketika di bawah ufuk, rukyat dilaksanakan untuk mendapatkan dasar penetapan istikmal. 


\section{d. Lokasi Rukyat}

Rukyat yang dilaksanakan oleh Nahdlatul Ulama dalam setiap bulannya tidak kurang dari 59 lokasi rukyat yang tersebar di seluruh wilayah Indonesia. lokasi-lokasi penyelenggaraan rukyat ditetapkan berdasarkan pertimbangan: a. Bahwa di lokasi dimaksud telah terbukti adanya keberhasilan usaha rukyat pada waktu-waktu sebelumnya; b. Bahwa secara geografis dan astronomis lokasi dimaksud memungkinkan terjadinya rukyat; c. Berdasarkan usulan/laporan dari PWNU/PCNU setempat. Di bawah ini adalah nama lokasi rukyat yang konsisten melaksanakan rukyat, baik dalam menentukan bulan Ramadan, Syawal dan Zulhijah maupun bulan yang lainnya (LF PBNU, 2006).

2. Bersama-sama Mengawali Awal Bulan dengan Pemerintah

Jika Pemerintah menetapkan awal Ramadan, Syawal dan Zulhijah beradasarkan landasan al-qur'an dan al-sunah yakni rukyat, maka keputusan atau isbat pemerintah tersebut oleh Nahdlatul Ulama akan diikuti, sehingga NU dan Pemerintah bersama-sama memulai awal bulan. Namun, apabila keputusannya mengabaikan rukyat hanya berlandaskan hisab saja, maka NU akan berbeda dengan Pemerintah. Ini bukti bahwa NU berdiri sendiri, mempunyai dasar pegangan, bukan selalu mengikuti Pemerintah. Sikap NU ini tertuang dalam ikhbar, dimana ikhbar dikeluarkan setelah NU ikut andil dalam sidang isbat.

Ikhbar merupakan sikap NU menilai secara jernih sesuai degan pedoman yg dipegang NU (Masroeri, 2018). Ikhbar PBNU ini memiliki fungsi sebgaia berikut:

1. Menyampaikan pendirian NU tentang awal Ramadan, Syawal, dan Zulhijah.

2. Memperkuat isbat Menteri Agama jika diterbitkan berdasarkan rukyat.

3. Sebagai koreksi terhadap isbat Menteri Agama ketika diterbitkan dengan mengabaikan rukyat (Masroeri, 2011)

Walaupun NU ikut andil dalam sidang isbat, tetapi ikhbar NU tidak selamanya mengikuti hasil isbat pemerintah, pada saat tertentu bisa berbeda. Dalam hal isbat Menteri Agama mengabaikan rukyat, maka kedudukan ikhbar PBNU mempunyai nilai isbat, yakni dapat berlaku umum bagi umat Islam di Indonesia (Masroeri, 2018). Perbedaan ini bukan berarti NU melawan Pemerintah dan tidak mengikuti kodifikasi Madzahibul Arba'ah yang menyatakan isbat hakim (pemerintah) wajib diikuti karena dapat menghilangkan perbedaan. Perbedaan ini disebabkan karena pemerintah yang menetapkan awal bulan tidak sesuai dengan landasan al-qur'an dan hadis dengan mengabaikan rukyat maka tidak wajib diikuti (Masroeri, 2018). 
3. Praktik di Lapangan

Kriteria Imkan al-rukyah MABIMS (Menteri Agama Brunei, Indonesia, Malaysia, dan Singapura) yang dianut oleh pemerintah dan diadopsi oleh NU, tersusun berdasarkan pengalaman empirik pengamatan hilal awal Ramadan 1394 H/16 September 1974 yang dilaporkan oleh 10 saksi dari 3 lokasi yang berbeda. Tidak ada indikasi gangguan planet Venus. Perhitungan astronomis menyatakan tinggi hilal sekitar 2 derajat dengan beda azimut 6 derajat dan umur bulan sejak ijtimak 8 jam. Jarak sudut bulanmatahari 6,8 derajat, dekat dengan limit Danjon yang menyatakan jarak minimal 7 derajat untuk manusia rata-rata (Djamaluddin, 2005).

Sejak tahun 1964 yang tercatat di Departemen Agama (sekarang Kementerian Agama), sudah puluhan kali hilal dapat dilihat. Bahkan terjadi beberapa kali hilal di bawah $5^{\circ}$ dapat dilihat di berbagai tempat. Sebagai contoh, hilal awal Syawal $1404 \mathrm{H}$ yang ketinggiannya sekitar $2^{\circ}$ dengan saat ijtimak jam 10.18 WIB, 29 Juni 1984, dapat dilihat oleh: (1) Muhammad Arief, 33 tahun Panitera Pengadilan Agama Pare-Pare, (2) Muhadir, 30 tahun, bendahara Pengadilan Agama Pare-Pare, (3) H. Abdullah Hamid, 56 tahun Guru Agama Jakarta, (4) H.. Abdullah, 61 tahun, Guru Agama Jakarta, (5) K. Ma'mur, 55 tahun, Guru Agama Sukabumi, (6) Endang Effensi, 45 tahun, Hakim Agama Sukabumi (Widiana, 2004).

4. Menghindari Orang-Orang yang Berlaku Manipulatif

Menurut Ghozalie Masroeri, untuk menghindari orang-orang yang berlaku manipulatif penting adanya kriteria Imkan al-rukyah. Sebab, rukyat diperbolehkan adalah rukyat yang dalam prosesnya benar-benar membidik dan melihat hilal secara langsung, baik menggunakan alat bantu modern seperti teleskop maupun dengan mata telanjang. Tidak dibenarkan rukyat dengan melihat ke cermin atau air karena yang dilihat bukanlah hilal secara langsung melainkan pantulannya, ini dapat menimbulkan kekeliruan bahwa yang dianggap cahaya hilal ternyata cahaya polusi di sekitar lokasi (Masroeri, 2018). Dijelaskan oleh Ma'ruf Amin bahwa pada prinsipnya Syariah tidak menolak keikutsertaan IPTEK dalam proses penentuan awal dan akhir Ramadan, selama tidak bertentangan dengan syariah atau mengabaikan petunjuk yang telah diberikan syariah. Namun syariah tidak menuntut sejauh itu supaya tidak memberatkan umat, selengkapnya( Amin, 1994).

Masroeri menjelaskan, adanya kriteria Imkan al-rukyah, maka ketika ada laporan hilal dapat terlihat dan memiliki bukti berupa foto, padahal menurut hisab hakiki tadkiki ashri atau kontemporer data hilal menunjukan masih di bawah Imkan al-rukyah, kesaksian tersebut dapat ditolak. Lain halnya ketika data hilal sudah mencapai Imkan al-rukyah, langkah selanjutnya adalah menguji keorisinilan rukyat tersebut. Sebagai contoh Ghozalie Masroeri 
menyampaikan bahwa ada kiriman foto dari lokasi rukyat Masjid Agung Jawa Tengah, kemudian dipertanyakan apakah orisinil atau tidak, kalau orisinil apa yang menjadi indikator orisinilitasnya. Setelah diteliti dan dikontrol ternyata dalam proses rukyatul hilal tersebut hasil foto merupakan tangkapan langsung dari lubang pengintai teleskop tanpa adanya olahan citra yang dapat memanipulasi sesuatu (hilal) yang tidak ada menjadi ada (Masroeri, 2018).

Pada dasarnya, NU tidak mematok kriteria 2 derajat tinggi hilal, 3 derajat elongasi dan 8 jam umur Bulan. Karena MABIMS menentukan kriteria tersebut dan ternyata secara empirik ada warga NU yang dapat melihat hilal pada kriteria itu, maka oleh NU kriteria tersebut dijadikan sebagai pengontrol untuk mewujudkan rukyat yang berkualitas. Adapun tawaran kriteria baru dengan indikator tinggi hilal 3 derajat dan elongasi 6,4 derajat, NU menolaknya, karena pada akhirnya kriteria tersebut akan meninggalkan rukyat dan menggantinya dengan hisab.

\section{PENUTUP}

Penolakan Pengurus Besar Nahdlatul Ulama terhadap kesaksian rukyat di bawah Imkan al-rukyah dari tahun 1998-2017 terjadi sebanyak 9 (sembilan) kali, yaitu tahun 1998, 2001, 2002, 2006, 2007, 2011, 2012, 2013 dan 2017. Penolakan tersebut dilakukan oleh Pengurus Besar Nahdlatul Ulama (PBNU) karena menurut hisab kontemporer di lokasi rukyat belum mencapai kriteria Imkan al-rukyah dengan indikator minimal tinggi hilal 2 derajat, umur bulan 8 jam, atau jarak Matahari-Bulan 3 derajat. Secara syar'̄̄, didasarkan pada pendapat Ibn Hajar al-Haitami yang menyatakan bahwa syahadat (kesaksian melihat hilal) dapat ditolak jika ahli hisāb sepakat memustahilkannya, dan dapat diterima jika para ahli hisāb masih memperselisihkannya. Adapun alasan PBNU menjadikan kriteria Imkan al-rukyah sebagai dasar penolakan adalah; (1) untuk meningkatkan kualitas rukyat dengan didukung oleh Metode hisab tahkiki tadkiki/ashri, NUMO (Nahdlatul Ulama Mobile Observatory), rukyat setiap bulan kamariah, banyaknya lokasi rukyat ideal; (2) Bersama-sama mengawali awal bulan dengan pemerintah; (3) Praktik di lapangan; dan (4) Menghindari orang-orang yang berlaku manipulatif.

Adapun saran penulis demi terciptanya konsistensi rukyat sebagai penentu awal bulan kamariah adalah; Pertama, dengan konsistensi NU dalam menerapkan imkan al-rukyah di masing-masing lokasi rukyat, secara tegas NU dapat menolak apabila terdapat kesaksian rukyat yang jelas secara perhitungan kontemporer belum memenuhi batas minimal imkan alrukyah. Tetapi jika pada saat penetapan ternyata pemerintah melalui sidang isbat justru menerima kesaksian tersebut dan menjadikan dasar rukyat sebagai penentu masuknya bulan baru, maka NU tidak perlu melakukan istikmal, melainkan taat terhadap keputusan pemerintah demi menghilangkan perbedaan; Kedua, pada saat ketinggian hilal di seluruh wilayah Indonesia telah mencapai batas minimal imkan al-rukyah, namun faktanya tidak ada yang berhasil melihat hilal, maka NU menetapkan awal 
bulan atas dasar istikmal, walaupun pada saat itu pemerintah melalui sidang isbat akan menetapkan berdasarkan hisab imkan al-rukyah. Karena pemerintah menetapkan masuknya bulan baru hanya berdasarkan hisab dan mengabaikan rukyat, NU tidak perlu taat dan ikut ketetapan tersebut. 


\section{DAFTAR PUSTAKA}

Amin, Ma'ruf, (1994), "Rukyah untuk Penentuan Awal dan Akhir Ramadan Menurut Pandangan Syariah dan Sorotan IPTEK" dalam Rukyah dengan Teknologi (Upaya Mencari Kesamaan Pandangan tentang Penentuan Awal Ramadan dan Syawal), Jakarta:Gema Insani Press.

Amri, Rupi'i, "Upaya Penyatuan Kalender Islam Indonesia (Studi atas Pemikiran Thomas Djamaluddin)", Ishraqi, Vol. 10, No. 1, Juni 2012.

Anggaran Rumah Tangga Nahdlatul Ulama dalam Pengurus Besar Nahdlatul Ulama, (2015), Anggaran Dasar \& Anggaran Rumah Tangga Nahdlatul Ulama, Jakarta:Lembaga Ta'lif wan Nasyr PBNU.

Bruinessen, Martin van, (1994), Traditionalist Muslim in A Modernizing World: The Nahdlatul Ulama Ana Indonesian's New Order Politics, Fictional Conflict, and The Search for a New Discourse, diterjemahkan oleh Farid Wajidi dengan judul "NU : Tradisi, Relasirelasi Kuasa, Pencarian Wacana Baru, Yogyakarta : LKiS.

al-Bukhari , Muhammad Ibn Ismail, (1403 H), Sahịh al-Bukhārī, juz 2, Mesir:al- Maktabah al- Salafiyah, cet. 1.

Direktorat Jendral Bimbingan Masyarakat Islam Kementrian Agama RI, (2010), Almanak Hisab Rukyat, Jakarta: Direktorat Jendral Bimbingan Masyarakat Islam Kementrian Agama RI.

Djamaluddin, Thomas, (2005), Menggagas Fiqih Astronomi (Telaah HisabRukyat dan Pencarian Solusi Perbedaan Hari Raya),Bandung:Kaki Langit.

al-Haitami, Ibn Hajar, (1983), Tuhfat al-Muhtāj bī Syarh al-Minhāj, juz 3, Mesir : at-Tijariyah al-Kubro.

Hambali, Slamet, (2012), "Fatwa Sidang dan Penyatuan Kalender Hijriyah", kumpulan makalah Lokakarya Internasional Penyatuan Kalender Hijriyah:Sebuah Upaya Pencarian Kriteria Hilal yang Obyektif Ilmiah, Semarang: Elsa Press.

Hosen, Ibrahim, (2004), "Penetapan Awal Bulan Qamariah Menurut Islam dan Permasalahannya", dalam Selayang Pandang Hisab Rukyat 
Jakarta: Direktorat Jenderal Bimas Islam dan

Penyelenggaraan Haji

Direktorat Pembinaan Peradilan Agama.

Ikhbar/pemberitahuan hasil rukyatul hilal awal Muharram $1439 \mathrm{H}$ Pengurus Besar Nahdlatul Ulama 23 September 2017 M.

Izzuddin, Ahmad, (2007), Fiqih Hisab Rukyat : Menyatukan NU \& Muhammadiyah dalam Penentuan Awal Ramadan, Idul Fitri, dan Idul Adha, Jakarta : Erlangga.

Jayusman, "Isyarat Penentuan Awal Bulan Kamariah dalam al-Qur'an; Mencermati Perbedaan Kriterian dan Metode Penetapan Awal Bulan Kamariah di Indonesia", Al-Dzikra Vol. 5 No. 9 Juli-Desember Tahun 2011.

Junaidi, Ahmad, "Imkan al-Ru'yat sebagai Pemersatu Kalender Islam: Memadukan Ru'yat NU dan Hisab Muhammadiyah dalam menentukan Kalender Islam". Dimuat dalam Dialogia, Vol. 8 No. 2, Juli 2010.

Keputusan Musyawarah Nasional Alim Ulama Nahdlatul Ulama Nomor I/MAUNU/1404/1983 tentang Hukum atas Beberapa Masalah Diniyah dalam Hasil Muktamar NU ke 27 Situbondo Nahdlatul Ulama Kembali ke Khittah Perjuangan 1926, Semarang:Sumber barokah, 1985.

Lajnah Falakiyah PBNU, (2006), Pedoman Rukyat dan Hisab Nahdlatul Ulama, Jakarta: LF PBNU.

Kramat Raya no. 164 Jakarta Pusat. “Arship LF PBNU” di kantor PBNU jl. , Laporan Lajnah Falakiyah Kepada PBNU Tentang Penyelenggaraan Rukyat untuk Idul Fitri 1427 H, Jakarta: LF PBNU.

, Pedoman Penyelenggaraan

Organisasi Lajnah Falakiyah Nahdlatul Ulama, Jakarta: LF PBNU.

Masroeri , A. Ghazalie, (2011), Penentuan Awal Bulan Kamariah Perspektif NU, Jakarta: Lajnah Falakiyah Pengurus Besar Nahdlatul Ulama. 
Nawawi, Abd Salam, (2004), Rukyat Hisab di Kalangan NU Muhammadiyah (Meredam Konflik dalam Menetapkan Hilal), Surabaya:Diantama dan Lajnah Falakiyah (LF) NU Jatim.

Pengurus Besar Nahdlatul Ulama, (1985), Hasil Muktamar Nahdlatul Ulama ke 27 Situbondo,Semarang:Sumber Barokah.

Sakirman, "Menelisik Metode Hisab-Rukyat di Indonesia", Hunafa: Jurnal Studia Islamika Vol 8 No 2 (2011).

SK PBNU NO. : 311/A.II03/I/1994 tentang Pedoman Oprasional Penyelenggaraan Rukyat Bil Fi'li di Lingkungan Nahdlatul Ulama dalam Lajnah Falakiyah PBNU, Pedoman Rukyat dan Hisab Nahdlatul Ulama, Jakarta: LF-PBNU, 2006.

Wawancara dengan K. H. A. Ghazalie Masroeri di kantor PBNU j1. Kramat Raya no. 164 Jakarta Pusat pada tanggal 22 Febuari 2018.

Wawancara dengan Nahari Muslih di kediaman beliau pada tanggal 24 Febuari 2018.

Wawancara dengan Slamet Hambali di Pascasarjana UIN Walisongo pada tanggal 27 Oktober 2017.

Wawancara dengan Sayful Mujab pada tanggal 11 April 2018 di Pascasarjana UIN Walisongo.

Widiana, Wahyu, (2004), "Pelaksanaan Rukyatul Hilal di Indonesia", dalam Selayang Pandang Hisab Rukyat Jakarta: Direktorat Jenderal Bimas Islam dan Penyelenggaraan Haji Direktorat Pembinaan Peradilan Agama. 